\title{
A HISTORY OF THE IRISH ACCOUNTING AND FINANCE ASSOCIATION 1987-2012
}

\author{
Bernard Pierce \\ Dublin City University \\ Keith Warnock \\ National University of Ireland, Galway \\ Aileen Pierce \\ University College Dublin
}

\begin{abstract}
$\mathrm{T}$ his paper was written to mark the occasion of the $25^{\text {th }}$ annual conference of the Irish Accounting and Finance Association (IAFA). It draws heavily on Warnock and Pierce (2006), which presented a history of the first eighteen years of the Association. The paper first discusses the background to the formation of the Association, and then traces its history from its inaugural conference in 1987 to date. It considers attempts to balance the interests of its different institutional and geographical elements as the range and number of its activities increased. The support of professional accounting bodies and overseas academics in this development is acknowledged. The paper records the publication of volumes of Proceedings from some of the early annual conferences, and the development from that base of the Irish Accounting Review. This is followed by a brief discussion of a number of initiatives to support and encourage research that formed part of the Association's role in the development of a research ethos within the Irish academic accounting community. The paper concludes with a brief look ahead to some of the challenges facing the Association in the future.
\end{abstract}

\section{INTRODUCTION}

The formation of any academic association requires the existence of some critical mass of potential members. For many years after an accounting academic was first 
appointed to an Irish university, there was no realistic prospect of the formation of an association. The date of that first appointment might be disputed. Zeff $(1997$, p. 6) acknowledges that 'the earliest full-time chair in a $\mathrm{UK}^{1}$ university with Accountancy or Accounting in its title' was filled in 1914 with the appointment of Bernard Francis Shields as Professor of Commerce and Accountancy at University College Galway (UCG) (now National University of Ireland, Galway (NUI Galway)). Professor Shields later moved to University College Dublin (UCD) as Professor of Commerce. ${ }^{2}$ However, neither he nor his successor in Galway 'was a qualified accountant, and neither published any works on accountancy' (Zeff, 1997, p. 6).

Desmond Hally became the first full-time lecturer in accountancy at any Irish university (UCD) in 1965; in 1971 he became the first full-time Professor of Accountancy when he was appointed to the chair at the same institution (Colbert, 2000). In a university system where faculties such as science and arts were longer established and significantly larger, departments ${ }^{3}$ in the field of commerce were relatively slow to grow. In UCD, there was one other full-time accountancy appointment in the 1960s, two more in the early 1970s, and one in 1979. Two further appointments in 1980, partially offset by the departure of Seamus Collins to become the first fulltime Professor of Accountancy and Finance at UCG, created a department of six full-time academics in UCD, the largest in the Republic of Ireland at the time.

The appointment of Seamus Collins in 1980 brought the number of full-time accounting academics in UCG to three. There were at that time departments of similarly limited size in Trinity College Dublin (TCD), University College Cork (UCC), and the National Institutes of Higher Education in Dublin (NIHED) (now Dublin City University (DCU)) and in Limerick (now the University of Limerick (UL)). In Northern Ireland's two main third-level institutions, the number of full-time academic accountants in Queen's University Belfast (QUB) was also similar, while the larger number in the Ulster Polytechnic (later the University of Ulster at Jordanstown (UUJ)) was explained by its provision of a significant number of professional accounting programmes. The Republic's Regional Technical Colleges (RTCs) (now Institutes of Technology) also contributed to the growth in numbers of accounting academics in Ireland from their foundation in the early 1970s.

From one perspective, it might be claimed that by 1980 the number of Irish accounting academics was sufficient to support the formation of an association. From another, it might be argued that it was not. The history of the British Accounting Association (BAA) suggests that, with hindsight, it may have been appropriate that no efforts were made to start an association in the early 1980s in Ireland. Zeff (1997) argues that the early years of the Association of University Teachers of Accounting (AUTA) (the predecessor of the BAA, which became the British Accounting and Finance Association (BAFA) in 2011) were heavily dependent on two individuals, William Baxter and David Solomons, both of the London School of Economics (LSE). The pool of potential members was, admittedly, even more limited than in the Ireland of 1980: in 1949, this pool amounted to '... 29 (apart from special lecturers), of whom only seven were full-time' (Zeff, 1997, p. 16). Newsletters were published and conferences were held (in 1947, 1949, 1950, 1952, 1955 and 1958), but neither these nor the other activities undertaken were, apparently, sufficient to 
create a fully sustainable association; in the words of Zeff (1997, p. 29), 'following Solomons' departure for America in 1959 ... the Association became dormant'.

Parker (1997, p. 41) takes up the story of the AUTA/BAA where Zeff (1997) left off, and describes the organisation as 'lapsing into near extinction in the early [1960s]'. Although the number of full-time academic accountants had increased to 21 by 1960, and continued to grow during that decade, no formal conferences were held during the period. By the end of the decade, however, Parker (1997, p. 47) suggests, an 'increase in professorial appointments from 1967 onwards' had created the climate for the continuing vitality of the AUTA. Following the revival of the newsletter and the holding of an informal conference in the University of Kent in June 1968, the first of an unbroken series of annual conferences was held (also in Kent) in 1971. Maunders $(1997$, p. 63) reports that the attendance at that conference was 62, and that the total membership for 1972-1973 was 114. From his paper, it is clear that the British academic accounting community had now reached a size where the Association's sustainability was no longer in doubt.

As suggested above, in the light of the history of the AUTA/BAA, it may have been fortuitous that no premature attempt was made to create an association in Ireland. However, during the 1980s the number of academic accounting posts continued to increase throughout the island, and those who had been appointed in earlier decades began to look at the possibilities for greater interaction between the various universities and other institutions. For instance, a number of seminars were held to which the host university invited academics from some other institutions. In a major step forward in 1987, however, all third-level institutions and accounting academics in Ireland received an invitation to a one-day conference in Dublin. ${ }^{4}$ The joint purposes of the conference were to hear six invited papers and to discuss the possibility of establishing an Irish academic accounting association.

\section{THE INAUGURAL CONFERENCE AND THE FOUNDING OF THE ASSOCIATION}

The organisers of what was subsequently described as the inaugural conference had no clear idea of how many third-level teachers of accounting there were in Ireland, let alone how many were likely to respond to the invitation issued. Some support would obviously come from the institutions of those presenting papers (see Appendix 1). However, that did no more than guarantee some attendance from the three largest institutions in Dublin. In the event, the number (41) attending Trinity College on 2 April 1987, and the range of institutions (14) represented, exceeded all expectations. There were twelve representatives from the Dublin institutions from which the majority of presenters came, but the largest grouping was from the Colleges of Commerce, which later became the Dublin Institute of Technology (DIT). There were also delegates from four of the Republic's Regional Technical Colleges (Athlone, Cork, Galway and Waterford). This broad representation ensured that an important goal of the fledging association - continued participation of accounting academics from the non-university sector - was being met. 
Pierce, Warnock and Pierce

The delegation from the Colleges of Commerce was matched in size by that from Queen's University Belfast, and there were also a number of representatives from the University of Ulster. This significant Northern Ireland presence meant that another important goal for any emerging association would be the maintenance of an appropriate balance in activities between north and south. ${ }^{5}$ Potentially, every organisation in Ireland must decide whether it will operate on an all-Ireland basis or solely within either the Republic of Ireland or Northern Ireland. Sometimes the outcome is influenced by the time of origin of the organisation: if it began its life before the foundation of the Irish Free State (which later became the Republic of Ireland) in 1922, then it will almost certainly have originated as an all-Ireland body. A relevant example of this is the Institute of Chartered Accountants in Ireland (ICAI), now known as Chartered Accountants Ireland, which was founded in 1888 (Robinson, 1964, p. 87). Its foundation was in response to a petition for a Royal Charter, and of the thirty-one petitioners, thirteen were from Dublin, twelve from Belfast (in what subsequently became Northern Ireland) and six from Cork (Robinson, 1964, pp. 85-86). When the Irish Free State was founded, the ICAI continued on an all-Ireland basis. ${ }^{6}$ The constitution of the ICAI ensures that its governing council has a certain minimum representation from Northern Ireland, and the presidency of the Institute is, by convention, held by a member from the north on a regular basis. The success of the ICAI in achieving an appropriate geographical/political balance in its operations was a potential model for any emergent academic association in accounting.

The success of the inaugural conference inevitably encouraged a wish for the formation of a permanent association. It was decided that a conference would be held the following year in QUB (reflecting the number of representatives from Queen's at the inaugural conference), and that at that conference a constitution would be agreed for such an association. Accordingly, the first annual conference of the Irish Accounting Association ${ }^{7}$ took place in Belfast on 24-25 March 1988. The first annual general meeting was held on 24 March 1988 (see Appendix 2), and the Association came into formal existence with the adoption of a constitution. The objectives of the Association were stated as 'the advancement of Accounting and related disciplines in the education and research fields in the Republic of Ireland and Northern Ireland' (Irish Accounting Association, 1988a, p. 1). By the time of that first annual conference the potential for the ongoing success of the Association was already clear. The number of papers presented doubled to twelve. As well as authors from NIHED, UCD and TCD, there were contributions from UCC, the University of Ulster and QUB. The attendance at the inaugural conference was comfortably surpassed.

The next section of the paper traces the development of the Association's activities in the following years.

\section{THE DEVELOPMENT OF THE ASSOCIATION}

The maintenance of a well-attended annual conference, with an increasing number of papers, was a central part of the early activity of the Association. The importance of the conference has not diminished over the years. However, successive chairpersons and councils have sought continuously to broaden the range of the 
Association's activities: initiatives have included actively recruiting the sponsorship of professional accounting bodies to support day-long seminars, introducing newsletters and a website, and persuading well-established academics from other countries to visit and provide workshops for members of the Association. More recent initiatives have included the annual doctoral colloquium, the IAFA Scholar Award, the annual doctoral research funding competition and the first research webinar. This section of the paper looks at a number of these areas of the Association's activities, beginning with the annual conferences.

\section{Annual Conferences}

Following the inaugural conference in TCD and the conference in QUB at which it came formally into existence, the Association has succeeded in staging a successful conference on an annual basis. The full list of locations is set out in Appendix 3. In the early years of the Association, in keeping with the sensitivity to diversity which was alluded to earlier, the locations for the conferences followed a very strict sequence. After conferences in the two major cities of Dublin and Belfast, the next conference (the second annual conference) was held in the Republic of Ireland, but outside Dublin: it was hosted jointly by UCC and the Regional Technical College, Cork. That pattern was maintained in the following six years. In the next three-year cycle there were conferences successively in Dublin (at DCU), in Belfast (at the University of Ulster at Jordanstown) and in the Republic outside Dublin (at UCG); in the subsequent three-year cycle the pattern was repeated with conferences held in UCD, in QUB for the second time, and in the University of Limerick.

The strict sequence was then broken. The immediate cause was the request by the Regional Technical College in Dundalk to stage the ninth annual conference. This was precipitated by the wish to mark the College's twenty-fifth anniversary, but was also motivated by a desire to secure recognition of the contribution to the Association of the institutions from the non-university sector. Almost certainly the sequence would have changed anyway. Although it resumed with conferences in Dublin (DCU for the second time), in the Republic outside Dublin (in UCC), and in the University of Ulster at Coleraine, it then became clear that it was unrealistic to expect one of the limited number of institutions in Northern Ireland to be prepared to host a conference every three years. In the fourteen conferences taking place after that in Coleraine, the Association has returned to Northern Ireland only twice, in 2004 to QUB and in 2010 to University of Ulster, Belfast. The hosting of the thirteenth conference in DIT in 2000 led a significant expansion in the hosting of annual conferences outside of the university sector, with five of the following conferences being held in institutions in the non-university sector.

What started as a carefully devised pattern to ensure an appropriate equity of treatment between Northern Ireland and the Republic has developed into an eclectic mix of factors which determine the location of the annual conference. As with many aspects of the Association's operations, it works as a blend of responses to institutional desires to stage a conference and persuasion from the council when insufficient volunteers come forward.

Following the first annual conference in 1988, at which 12 papers were presented, the number of papers steadily grew and had doubled to 24 by the time of 
the 1993 conference in UCD. The number rose to 40 for the 1997 conference in DCU and thereafter has tended to fluctuate between 40 and 50 .

From publication of its first volume in 1993, the Irish Accounting Review has published a complete list of papers presented at each annual conference. An analysis of the papers from that year's conference and at four-yearly intervals thereafter gives an indication of the relative popularity of subject areas in providing topics for conference papers. Appendix 4 presents a summary of papers analysed at four-yearly intervals by subject area from 1993 to 2009 inclusive. Subject areas were determined based on guidance from Ashton et al. (2009) and Helliar, Monk and Hannah (2010). While the percentage of papers from each subject area shows wide fluctuations, the largest proportion understandably came from the general area of Finance. The next most popular areas were Financial Accounting and Reporting, Accounting Education/Profession, and Management Accounting, in varying orders depending on the particular year.

Analysis of conference paper authors' institutions on a four-yearly basis over the period 1993-2009 is presented in Appendix 5. In the earlier years of the analysis, 1993 and 1997, a notable feature was the high proportion of papers originating from the two Northern Ireland universities. At the same time, the proportion of presenters from non-Irish universities was also relatively high. Thereafter, the proportion of papers originating in universities in the Republic of Ireland increased, signalling a growing emphasis on research and a significant increase in the number of active researchers compared to earlier periods.

An interesting trend appears from an analysis of the number of authors for each conference paper presented over the same period, summarised in Appendix 6. Papers were analysed according to the number presented by one, two, three or four authors. For each of the four years selected from 1993 to 2005 inclusive, single authorship was most popular. A notable shift occurred in 2009, with a significant drop in the proportion of papers presented by a single author and an increase in the proportion of papers presented by two, three and four authors. By 2009, the majority of papers were presented by two authors.

An important element of each annual conference has been a plenary session featuring an invited speaker. The majority of these speakers have come from abroad, mostly Britain and the United States, and most are academics. Occasionally, however, there have been exceptions, such as in 2001 when the Irish Comptroller and Auditor General presented the plenary session. A list of plenary speakers and topics is shown in Appendix 7.

Securing adequate sponsorship is a recurring theme in the organisation of the annual conference, ensuring that the occasion is enjoyable socially as well as academically and, more importantly, helping to maximise attendance, particularly from those institutions with lower levels of financial support for research-based activity. The Association was fortunate to secure sponsorship from the Chartered Institute of Management Accountants (CIMA) at an early stage, and this generous support has continued for many years. Each conference organiser takes responsibility for additional fund-raising, which frequently is provided by local accounting firms (often the local offices of the major international firms) or local businesses. The host institutions provide support through the provision of facilities, an aspect 
of conference organisation which can no longer be taken for granted as universities and other third-level institutions become increasingly commercial in their approach to many activities.

Numbers attending annual conferences vary with the location, with Dublin clearly the most attractive venue. In the earlier years of the Association, some (both from abroad and within Ireland) would have had doubts about the safety of Belfast, which tended to restrict numbers there. In the Republic, locations outside Dublin would be perceived as varying in accessibility. Statistics on actual conference numbers are not always available, but since attendance at the conference is by far the dominant source of membership, the record presented in Table 1 of membership numbers (partly estimated based on membership income for certain financial years) gives a reasonable idea of the levels of participation.

TABLE I: MEMBERSHIP NUMBERS

\begin{tabular}{lclc}
\hline Year Ended & Membership & Year Ended & Membership \\
\hline 31 December 1988 & 30 & 28 February 2000 & 123 \\
28 February 1989 & 35 & 28 February 200I & 163 \\
28 February 1990 & 28 & 28 February 2002 & 129 \\
28 February 199I & 70 & 3I December 2003 & 171 \\
28 February 1992 & 57 & 3I December 2004 & 113 \\
28 February 1993 & 67 & 3I December 2005 & 155 \\
28 February 1994 & 125 & 3I December 2006 & 128 \\
28 February 1995 & 118 & 3I December 2007 & 138 \\
28 February 1996 & 143 & 3I December 2008 & 108 \\
28 February 1997 & 170 & 3I December 2009 & 111 \\
28 February 1998 & 186 & 3I December 2010 & 128 \\
28 February 1999 & 125 & 3I December 201I & 148 \\
\hline
\end{tabular}

Attendance at the 1997 conference in DCU was probably the highest achieved. Of the 140 recorded as present, there were 104 Irish academics, 16 British academics, and 9 academics from Australia, New Zealand and North America; the balance of the attendance included representatives of professional accounting bodies and others.

\section{Chairperson}

In the early years, the chairperson of the Association was invariably linked to organisation of the annual conference. Thus, Tim Barrett of QUB became the first chairperson after the conference in Belfast, and was followed by Edward Cahill and Anthony Walsh after the conferences in Cork and at DCU respectively. Comparison of the full list of chairpersons in Appendix 8 and the conference locations presented in Appendix 3 shows that this relationship has been maintained in all but a few cases. However, the relationship has been broken on occasion. As pressures on time continue to increase, it may become more likely that an academic is prepared to 
Pierce, Warnock and Pierce

make the commitment to either anchor the organisation of the conference or chair the Association for a year, but not necessarily both.

\section{Council}

The affairs of the Association are managed by a council elected at the annual general meeting (AGM), itself invariably held as part of the annual conference. As with most voluntary organisations, membership of the council comes about through a combination of factors: newer members may wish to find out more about the Association and to have an opportunity to meet regularly with colleagues from different institutions; larger institutions may wish to have representation, and aim to ensure that as one council member from the institution retires, another is ready to go forward as a candidate; and the outgoing council may strive to ensure that there are sufficient candidates to fill the forthcoming vacancies in a way that safeguards adequate representation from north and south and from non-university institutions as well as from the universities. Another important motivating factor is the desire to ensure representation on council as part of an institution's bid to stage the annual conference.

There is little doubt that the council has succeeded in drawing its membership from a sufficient range of institutions to remain fully representative. The constitution of the Association provides for a council consisting of a chairperson, a secretary, a treasurer and six ordinary members, with the possibility of co-opting two additional members. There has consistently been adequate representation for the potential minorities - the Northern Ireland institutions and the non-university sector. The average numbers of council members from Republic of Ireland universities, Northern Ireland universities, and the non-university sector in the Republic of Ireland are shown in Table 2.

TABLE 2: AVERAGE REPRESENTATION ON COUNCIL

\begin{tabular}{|c|c|c|c|c|}
\hline \multirow[b]{2}{*}{ Institutions } & \multicolumn{4}{|c|}{ Period } \\
\hline & $\begin{array}{c}1988 / 1989- \\
1993 / 1994\end{array}$ & $\begin{array}{l}1994 / 1995- \\
1999 / 2000\end{array}$ & $\begin{array}{l}2000 / 2001- \\
2005 / 2006\end{array}$ & $\begin{array}{c}2006 / 2007- \\
2011 / 2012\end{array}$ \\
\hline $\begin{array}{l}\text { Northern Ireland } \\
\text { universities }\end{array}$ & $2.00(20.4 \%)$ & $2.00(19.7 \%)$ & $2.00(18.5 \%)$ & $1.50(14.0 \%)$ \\
\hline \multicolumn{5}{|l|}{ Republic of Ireland } \\
\hline - universities & $5.17(52.5 \%)$ & $4.00(39.3 \%)$ & $5.00(46.1 \%)$ & $5.17(48.5 \%)$ \\
\hline - non-university sector & $2.67(27.1 \%)$ & $4.17(41.0 \%)$ & $3.83(35.4 \%)$ & $4.00(37.5 \%)$ \\
\hline
\end{tabular}

The two universities in Northern Ireland have each maintained one member on the council throughout the life of the Association, except in the period 2010-2012, when representation from Northern Ireland dropped to one. Most of the universities in the Republic which have large departments of accountancy have also tended to maintain one member on the council, giving five such representatives during most of the 25-year period. Representation from the non-university sector in the Republic of Ireland has fluctuated. It started at a relatively low level, increased during the period 1994-2000 (at a stage where the possibility of hosting the annual conference 
in the institutions became recognised), and then levelled off. For the eight years up to 2007, the council was comprised of five academics from Republic of Ireland universities, two from the Northern Ireland universities, and four from the nonuniversity sector in the Republic. Since then, the composition of the council has been less consistent, ranging in total numbers between nine and fourteen, and representing the traditional constituencies in a variety of proportions from year to year.

There is regular turnover in the membership of the council. The constitution was revised in 1995 to require rotation. Three members must retire each year and are not eligible for re-election for two years; in the absence of voluntary retirements, those in office longest retire. Over the life of the association, more than 70 different members have served on the council, with an average period of service of just over three years. During the period 2006-2011 alone, 28 different members served on the council. Given the relatively small size of the Association, these figures represent a high participation rate.

The council met two or three times a year in the early years of the Association. Much of the council's time at this stage was spent on two topics: ensuring the successful continuation of the annual conference, the cornerstone of the Association's activities, and discussing the introduction of a journal.

Minutes of the first AGM in 1988 record the resolution 'that the possibility of a journal should be pursued' (Irish Accounting Association, 1988b). In the subsequent council meetings of 1988/1989, arrangements for the conference and the journal were 'the dominant issues on the agenda' (Irish Accounting Association, 1989a). Importantly, council minutes record (Irish Accounting Association, 1989b) that the Irish Accountancy Educational Trust (IAET) had agreed to provide financial assistance for publication. The IAET was established by the ICAI in 1981, and is funded annually by that body; its role is to provide grants for accountancy-related research and other relevant research projects. Although it was to prove some time before a regular journal was in place, this promise of financial support was a crucial factor in encouraging pursuit of the aim. The IAET has continued its support at a very generous level from the Association's first publication up to and including the present.

Perhaps the most interesting aspect of the minutes of this period is the report of correspondence from the British Accounting Association 'offering the pages' of the British Accounting Review to Irish contributors, and suggesting that the Irish Association refrain from publishing its own journal. 'The tone of the meeting was to reject the proposal and to proceed with plans for its own publication' (Irish Accounting Association, 1989c).

Management of the journal's production was also an issue. The minutes noted in relation to the planned publication from the 1989 conference that the 'appointment of an editor/editorial board was not resolved and it was left to the new committee to initiate a suitable review procedure in processing contributions for the journal and also the appointment of an editor/editorial board' (Irish Accounting Association, 1989c).

Discussions on the journal continued to dominate council activities, and the secretary's report to the 1990 AGM stated that the 'major issue was the progress of the journal, with respect to its funding, format and publication' (Irish Accounting Association, 1990). Discussion centred first around the ultimately abortive attempt 
to produce a volume of Proceedings from the 1989 conference and second on plans for publication of papers from the 1990 conference. Eventually, at the AGM of 1991, it was possible to report that the first publication had been achieved, Proceedings of the 1990 conference. The Association's publications are discussed more fully in a separate section below.

The start of another important aspect of the council's work in its early years may be traced to a meeting of 26 June 1992, when it was reported (Irish Accounting and Finance Association, 1992) that Andrea Jeffries (then of the Chartered Institute of Management Accountants), an early and valuable supporter of the Association, offered to arrange funding for a seminar by John Innes of Dundee University and Falconer Mitchell of Edinburgh University. The seminar was held on 14 November 1992 in Trinity College Dublin, and was the first of a very successful series. The council devoted considerable effort over the following years to building a pattern of such seminars by visiting academics, mainly from Britain but also from the United States, to help foster the research culture of which the annual conference remained the centrepiece. These seminars are considered more fully in the following subsection of the paper.

Whereas these seminars played one important role in fostering the research culture within the Association's membership, their benefit may have been greatest for established researchers. Conscious of this, and following 'a survey of members' interests and needs carried out by Professor Donal McKillop' (Irish Accounting and Finance Association, 2000), subsequent councils arranged the addition to the Association's programme of sessions designed to support those at the beginning of a research career; the first of these was organised by Bernard Pierce of DCU and presented by Pauline Weetman and Ted O'Leary. These, described as 'research seminars' (or occasionally 'workshops'), which was used to distinguish them from the existing stream of seminars, are also considered in a subsequent sub-section. Obviously, the border between seminars for established researchers and those for novice researchers is not clear-cut, and to a certain extent any division is arbitrary. However, it is important to note successive councils' awareness of the need to look after the interests of all constituencies in the Association. This attitude is further exemplified by the attempt to stage events of specific interest to those in the nonuniversity sector who may see their activities as exclusively focused on teaching. An example of an initiative in this area was the education seminar staged in Dundalk Regional Technical College in April 1995.

\section{Seminars}

As the Association looked to expand its range of activities, the provision of occasional seminars from visiting academics or other relevant speakers was an obvious avenue to explore. As in other areas, the approaches to the arrangement of such seminars were eclectic. Sometimes, a professional body might, as a result of an arrangement to sponsor an American academic's visit to Britain, offer to provide both the speaker and the related financial support to bring that academic to address the Irish audience. On other occasions, the readiness to provide financial support was indicated, and the Association itself arranged or sought out a suitable speaker. Appendix 9 sets out a list of some of the major speakers the Association has 
attracted, together with the sponsors of the session. A feature of the seminars is that members of the sponsoring professional body generally participate, and this provides some opportunity to increase dialogue between academics and practitioners.

Seminars in the early years were very well attended, attesting to their important role in the development of the research capacities and confidence of the membership. As an example, the November 1995 seminar by Robert Scapens of Manchester University (a frequent visitor to Ireland as a seminar speaker and as an external examiner) and Ken Simmonds of the London Business School attracted an attendance of fifty-two, made up of thirty-eight Irish-based academics, two British-based academics, eleven people from a business background and one civil servant.

Seminars sometimes featured a variety of sessions. For example, the morning session given by the Republic's then Attorney General, Michael McDowell, on 30 October 1999 was followed by a panel discussion, the panel including Gary McGann of the Jefferson Smurfit Group, a former president of the sponsors, the Association of Chartered Certified Accountants (ACCA).

The pause in the seminar series since 2010 might be attributed to, inter alia, the many opportunities now available to Irish academics to participate in a wide range of international conferences of both a general (e.g. the annual conference/ congress of the British, American or European Accounting Associations) or more focused nature, such as the BAFA Special Interest Group conferences on Auditing, Accounting Education and Financial Reporting, or the tri-annual conference of the Management Control Association. In recent years it has become more challenging to attract a critical mass of delegates to short-duration events run by the Association. In a move designed to improve ease of access and increase participation rates, the Association organised its first research webinar on 11 November 2011. This was presented by Jan Bebbington of the University of St Andrews, Scotland and Carlos Larrinaga of Universidad de Burgos, Spain. The topic of the webinar was Accounting for Sustainable Development: (Re-)Constructing the Agenda.

\section{Research Seminars/Workshops}

As the number of new academics grew and the importance of research was increasingly being recognised in the Irish university systems, both north and south, the provision of facilities to encourage those at the beginning of the research process was recognised. Few, if any, Irish university departments were large enough, or had a sufficient number of established researchers, to carry out the necessary development in-house, and the use of the growing network created by the Association was an obvious way forward. While the seminars discussed in the previous section were generally provided by speakers from outside Ireland, a feature of the research seminars/workshops was the cooperation between Irish and overseas academics in their provision. A schedule of those contributing to the series is set out in Appendix 10.

\section{Newsletters and Website}

As both the scale of Association activities and the number of different constituencies which the council attempted to serve increased, the publication of a newsletter was proposed. This was finally launched under the editorship of Niamh Brennan of UCD, with the first issue appearing in February 1996. Four issues were produced 
Pierce, Warnock and Pierce

in 1996 and another four in 1997. Early newsletters included a number of features that could not be continued indefinitely (such as a focus on a different third-level institution each year), so inevitably the number of issues was reduced in later years. Nevertheless, under the successive editorship of Thomas Stone (Institute of Technology, Tallaght (IT Tallaght)), Maeve McCutcheon (UCC), Tony Wall (UUJ), Antoinette Flynn (UL), John Casey (Waterford Institute of Technology (WIT)), Gerardine Doyle (UCD), Elaine Doyle (UL), Mark Cummins (DCU) and Kieran Gallery (UL), the newsletter continues to play a very important communication role, with two or three issues published every year.

The net cost to the Association of producing the hardcopy newsletter was significantly reduced by sponsorship from the Institute of Certified Public Accountants (ICPAI) in Ireland. Recent issues have been published electronically.

The development of a website was another important step in improving the communication structures of the Association. The initial website was set up by John McCallig of UCD in 1997. He maintained the site until its transfer to WIT in 2000. Subsequently, the website was maintained by Mark Mulgrew (then of QUB) and Brid Murphy (DCU) and was redeveloped under the stewardship of Philip Hamill of QUB. More recently, the website is maintained by Mark Mulgrew (now of DCU), under whose direction significant further development of the site is being carried out.

\section{Other Activities}

During 1993/1994 the council approved the preparation of two publications (Irish Accounting and Finance Association, 1994). The first was a catalogue of postgraduate accounting and finance theses and the second a directory of those working in the accounting and finance fields in Irish third-level institutions. The first edition of the Directory was produced in 1994, edited by Peter Clarke of UCD and Bernard Pierce of DCU. The second, in 1997, was edited by Peter Clarke and Bernadette Shannon of DIT. The 2000 edition was produced by Peter Clarke and Tony Brabazon, both of UCD. The latest edition (Sweeney and Barnes, 2004) was edited by Breda Sweeney of NUI Galway and Edel Barnes of UCC.

During the early 1990s, two members of the Association - Bernard Pierce and Niamh Brennan - were selected as nominees of the British Accounting Association to attend the annual doctoral colloquium of the American Accounting Association. In 1994, the Association was privileged to become an associate member of the American Accounting Association and was subsequently invited to make a nomination to its annual doctoral colloquium. The first nominee was Ciarán Ó hÓgartaigh of DCU, now an editor of the Irish Accounting Review. Appendix 11 presents a full list of nominees. Recommendations for the nomination are made by a panel of three judges from Irish institutions other than those where the candidates may be working or studying. Since the number of potential candidates is quite small, there is no policy of rotating the nomination between institutions or north and south; nevertheless, it is interesting to note that in practice there is a reasonable spread of institutions involved.

As a further support to emerging academics, the Association initiated the award of the title of 'IAFA Scholar' for the best paper submitted to the annual conference 
by a researcher falling within certain criteria designed to identify emerging scholars. The title was first awarded to Ann Marie Ward (then of UUJ) in 2004 and was subsequently awarded to Mark Hutchinson of UCC (2005), Jim Hanly of DIT (2006), Collette Kirwan of WIT (2009) and Stewart Smyth of QUB (2010).

Reflecting the growing number of members engaged in doctoral studies, the Association introduced an annual IAFA doctoral colloquium, scheduled to take place immediately prior to the annual conference. The first colloquium took place in the Institute of Technology, Tralee (IT Tralee) on 9 May 2007 and was facilitated by Sheila O'Donohoe of WIT and Ciarán Ó hÓgartaigh of DCU with Ruth Bender of Cranfield University and Joan Ballantine, then of QUB, as guest speakers. Subsequent colloquia were facilitated by Joan Ballantine of QUB (2008), Joan Ballantine of University of Ulster (UU) and Sven Modell of the University of Manchester (2009 and 2010), and Joan Ballantine of UU, Elaine Doyle of UL and Donal Byard of the City University of New York (2011). Patricia O'Brien of the University of Waterloo was also a guest speaker at the 2010 colloquium. The doctoral colloquium in 2012 was again facilitated by Joan Ballantine (UU), along with Chris Chapman (Imperial College London), Stephen Salter (the University of Texas at El Paso) and faculty members from NUI Galway.

Numbers participating in the colloquia have steadily increased, as have the number of papers presented by doctoral students. Eight papers were presented in 2009, while nine, sixteen and twenty papers were presented in 2010, 2011 and 2012 respectively. Additional streams were introduced in 2011 and 2012 to accommodate the increased number and range of doctoral student presentations.

Further support for members engaged in doctoral studies was introduced in 2009 in the form of an annual doctoral research funding competition. Prizes are awarded to students selected from those presenting their work at the IAFA doctoral colloquium. The prize winners for the four years since the competition was introduced are set out in Appendix 12.

\section{PUBLICATIONS}

The discussion in the previous section on the council showed the high importance attached to the introduction of a journal. As recorded there, the first publication of the Association was launched at the AGM during the 1991 conference. This was a volume of Proceedings from the 1990 conference held at DCU. Rather than a comprehensive record of all the papers presented, this was in fact a selection of papers submitted to a refereeing process after the conference. The volume was edited by Anthony Walsh and Dónal Keating of DCU, and contained revised versions of nine of the twenty-two papers presented. A similar process was undertaken the next year, with George Pogue and Michael Pogue of UUJ as editors; the resulting volume included eleven of the twenty-three conference papers. The final volume of Proceedings was edited by Seamus Collins and Keith Warnock of UCG; nine of the twenty-six papers from the 1992 Galway conference emerged from the reviewing and editing process. 
Pierce, Warnock and Pierce

In 1993/1994, the Association decided to commit itself to a regular journal, and the council eventually settled on the title Irish Accounting Review. The pattern of the previous publications was initially retained, however. Peter Clarke, organiser of the 1993 conference in UCD, was appointed editor and produced Volume 1 of the Review, with fourteen papers from the twenty-six presented at the conference included. An important development in this publication was the involvement for the first time of Brian O'Kane of Oak Tree Press. An accountant himself, he had acted as editor of Accountancy, the journal of the Institute of Chartered Accountants in England and Wales and one of Britain's most widely circulated business publications, before returning to Ireland to establish his own publishing company. His contribution extended far beyond that required by the business relationship between Oak Tree Press and the Review, and his advice proved invaluable in getting a journal established and seeing it through the initial years.

While Peter Clarke was working on the first volume of the Review, the council on 13 November 1993 appointed Noel Hyndman of QUB and Keith Warnock of UCG as joint editors (Irish Accounting and Finance Association, 1993). As they subsequently reported (Hyndman and Warnock, 1997), a further single issue was produced in 1995, and in 1996 two issues were published for the first time, a pattern that has continued to the present. Their 1997 paper discusses the editorial policy, which attempts to position the Irish Accounting Review as both an important outlet for Irish accounting academics and an international journal. Recognising that submissions to the Review come mainly from papers that have been previously presented at an IAFA annual conference, they analyse the papers presented at the 1997 annual conference in terms of geographical origin, finding that approximately 60 per cent came from Ireland, 25 per cent from Britain and the balance of 15 per cent mainly from North America, Australia and New Zealand. These figures are consistent with the analysis presented in Appendix 5 to this paper. Interestingly, Appendix 5 also shows that during the period 1997-2001 there was a marked decrease in the number of papers presented by international authors to less than 20 per cent - a decrease which coincided with a similar increase in papers originating in universities in the Republic of Ireland and which set a pattern in the origin of conference papers that has continued fairly consistently in the years that followed.

During 1998 the council approved the suggestion that a small editorial board should be appointed. The initial team of Peter Clarke of UCD, Donal McKillop of QUB and Bernard Pierce of DCU was supplemented in 2002 by the appointment of members from outside Ireland, many of whom had already had a significant amount of contact with the Association through involvement in its various activities. In 2004 the council appointed Ciarán Ó hÓgartaigh (then of DCU) as an additional editor. Following publication of its thirteenth volume, Keith Warnock stepped down from his position as editor at the end of 2006. The current editors and members of the editorial board are listed in Appendix 13.

In 2002, Brian O'Kane decided to discontinue his involvement with the Review, as the operations of Oak Tree Press changed their focus. By this stage, the editors were in a position to finalise production editing in-house. With an increased grant from the IAET, the editors (with the support of the council) decided to move to an enlarged format for the journal, and Volume 10 was the first to be produced in the 
new size and typeface. More recently, production of the journal has been undertaken by Orpen Press (previously Blackhall Publishing).

Initial publication of the Proceedings was made possible, and strongly encouraged, by the availability of finance from the IAET. The Trust's ongoing financial support of the Review has been vital, and covers almost all of the costs of publication. The costs of distribution and the balance of publication costs are covered from two sources: the Association's finances and the subscription revenue from sales of the journal to libraries. The membership subscription to the Association was increased in 1995 specifically to provide the funds needed for the second issue of the journal each year.

The Irish Accounting Review has been an important element in the establishment of a strong academic accounting community in Ireland. As Hyndman and Warnock (1997) point out, Irish academics who publish in the Review are often widely published elsewhere. Hyndman, Ó hÓgartaigh and Warnock (2006) explore further how that trend has developed over a number of years. Just as important is the inflow of papers from overseas. The result is a positive mixture of papers: some by established researchers, both from Ireland and overseas, some by researchers nearer the beginning of their academic career.

The journal is now available electronically through ProQuest and EBSCO.

\section{LOOKING BACK, LOOKING FORWARD}

As we look back over the 25 years since its inauguration in 1987, it is clear that the IAFA has much to celebrate and has probably far surpassed the expectations of those who initiated it. It is important to recognise the foresight and vision of a relatively small group of Irish academics whose commitment and energy secured the launch and rapid development of the IAFA. For many Irish academics, the IAFA has provided opportunities to develop their careers and a stepping stone into the international academic accounting community. For the teaching and research of accounting, it has provided an effective vehicle for keeping pace with change and with international developments.

It is also important to recognise the widespread and sustained commitment of its members and sponsors to the continued development of the IAFA. As briefly outlined in this paper, there has been a continuous flow of members who show willingness to serve on the council, organise activities and attend IAFA events. The record also shows evidence of innovative ideas to update the portfolio of activities and to find new ways to support teachers and researchers in accounting and to fulfil the mission of the IAFA.

What of the future? The challenges for accounting educators will undoubtedly grow, as educational institutions deal with an increasing array of pressures. The shortage of funding for third-level education has been well publicised and has been particularly visible over the past four years due to continued reductions in academic and administrative staffing levels. Pressure on public finances and much publicised proposals to rationalise the third-level sector in the Republic of Ireland give rise to speculation regarding structural change and possible change in status 
Pierce, Warnock and Pierce

for some institutions. Calls for increased transparency and accountability seek measures of return on investment in research and evidence of quality of teaching. Uninformed comment in the media and detailed questions regarding performance management and workloads of individual academics suggests a move towards micromanagement.

It seems inevitable that demands on individual academics in general will increase. These will include greater pressure to publish in quality publications, to demonstrate quality of teaching, to develop innovative programmes and methods of delivery and assessment, and to engage in service to the institution and the wider community. Demands on accounting academics in particular will go further. Criticisms of the accounting profession and of some practising accountants in recent years are not necessarily indicative of deficiencies in accounting education. They do, however, serve as a reminder of the need to continually question the relevance of what is taught, to maintain interaction with professional bodies and firms, and to seek effective integration between teaching, research and practice. In a time of reduced resources and a growing set of pressures, this represents a major challenge.

What will be the role of the IAFA in this rapidly changing environment? As in its first 25 years, the IAFA can continue to offer the potential to improve the quality of teaching and research, to enhance meaningful lifelong education for our students and alumni, to develop individual academics' careers and to contribute to the wider community. Some of the same challenges will need to be confronted, such as the need to ensure continued sponsorship and financial support. Some new ones will emerge, such as the use of technology in delivering its portfolio of activities and catering for a more diverse group of members in terms of research experience. Among its strengths, however, the membership of the IAFA now includes some very experienced researchers, which helps ensure sustainability of its activities with less reliance on the international academic community. It also has a significant cohort of members at relatively early stages of their research careers, as evidenced by the growing attendance at the IAFA doctoral colloquium, which helps ensure a vibrant research community into the future.

In spite of a vastly different environment, the ingredients necessary to harness the potential of the IAFA remain unchanged. It is important to recognise, however, that, because of the different context, these cannot be taken for granted. Fundamental to the continued success of the IAFA is a willingness of members to come forward, despite increasing demands and pressures, and make direct contributions to existing activities and to the development of new initiatives. Important also is the continuation of the spirit of collegiality and mutual support, balanced with an atmosphere that encourages constructive critique and intellectual rigour. Provided these essential attributes can be preserved, the IAFA will continue to provide significant benefits to its members and wider stakeholders.

\section{ACKNOWLEDGEMENTS}

The authors would like to thank many IAFA members, former secretaries, treasurers and chairpersons who helped them with detailed records included in this 
A History of the Irish Accounting and Finance Association 1987-2012

paper. They are also grateful to the participants of the 2012 annual conference of the Irish Accounting and Finance Association for helpful insights provided.

\section{NOTES}

Prior to 1922, the whole of the island of Ireland was part of the United Kingdom of Great Britain and Ireland. See Clarke (2005) for a more comprehensive discussion of Shields, including his significant publication output in business management and economic history.

3 For most of the period under consideration, universities in the Republic of Ireland were organised in a system of faculties and departments. Departments of accountancy were typically part of faculties of commerce. Although these descriptive terms were not universally applicable, they are used throughout this paper for convenience. In recent years, the traditional system of organisation has been subject to often controversial changes and proposals for change.

4 The invitation in turn required someone to take an initiative. It is believed that the origin of the Association can be traced to a meeting on 5 December 1986 at a corner table in the restaurant at the Belfield campus of UCD between Peter Clarke and Pearse Colbert of UCD and Pat McCabe and the late Edward Cahill of TCD.

5 Although the northernmost point of the island is actually in the Republic, the use of the phrase "the south" as equivalent to the Republic of Ireland and "the north" as equivalent to Northern Ireland is common.

6 This has sometimes created problems for the regulation of the accounting profession, an example being in the area of accounting standards. The Accounting Standards Committee included representatives from all six major accounting bodies in Britain and Ireland. Every standard produced by the Committee was promulgated by each of the bodies, and each separately obliged its members to follow the standard. Following the Dearing Committee report, the new Accounting Standards Board was no longer constituted on a representative basis, and the standards which it issued had legislative backing in the United Kingdom. However, the old arrangements continued in vestigial form in the Republic of Ireland, with the ICAI promulgating the standards to its members in the Republic in the absence of any direct legislative support.

The name and the objectives were expanded in 1991 to include specific reference to Finance. 
Pierce, Warnock and Pierce

\section{APPENDIX I: INAUGURAL CONFERENCE -TRINITY COLLEGE DUBLIN, 2 APRIL 1987}

IRISH ACCOUNTING ASSOCIATION

FIRST CONFERENCE PROGRAMME , THURSDAY 2nd APRIL I987

VENUE TRINITY COLLEGE DUBLIN, ARTSand SOCIAL SCIENCES BUILDING

(off Nassau St./Dawson St)

ROOM 3I26, First Floor.

IO. 20. REGISTRATION

IO.30. GENERAL INTRODUCTION

I0.40. First Paper, 'MANAGEMENT FRAUD : A CASE STUDY' Edward Cahil1 (TCD)

Chairman of Session Peter Clarke UCD)

II. 30 Second Paper, 'A'TTITUDES TO THE PROVISION OF FINANCIAL INFOR'ATION TO EMPLOYEES - INITIAL OBSERTATIONS AND RESEARCH PLANS' Patricia Barker (NIHE, Dub.)

Chairman of Session. Patricl: Mc Cabe (TCD)

I2.20 Third Paper 'ACCOUNTING FOR PENSIONS - WHITHER NOW'

Pearse Colbert (UCD)

Chairman of Session Keith Warnock (UCG)

I2.45 BREAK FOR LUNCH

2.00 Fourth Paper 'AGENCY THEORY AND MANAGEMENT ACCOUNTING: A CASE STUDY OF AND INTERNATIONAL COMPANY'

Eamon Wa1sh (LSE)

Chairman of Session Tim Barrett (QUB)

3.00. Fifth Paper ' THE QUALITY OF BUDGETING IN IRISH VOLUNTARY HOSPITALS' Donal Keating (NIYE, Dub)

Chairman of Session George Pogue (Uof U)

4.00 OPEN FORUM 'ISSUES AND OPPORTUNITIES FOR ACCOUNTING RESEARCH'

Panel: P Clarke, P Mc Cabe, GMc Hugh

4.30 SPECIAL GENERAL MEETING

- The establishment and organisation of an Irish Accounting Association ${ }^{\prime}$ 
A History of the Irish Accounting and Finance Association 1987-2012

APPENDIX 2: FIRST ANNUAL GENERAL MEETING - QUEEN'S UNIVERSITY BELFAST, 24 MARCH 1988

IRISH ACCOUNTING ASSOCIATON

Chairperson: T.F. Barrett, The Queens University, Belfast.

Secretary: P. Colbert University College, Dublin.

Treasurer: T.J. Riga, Cork Regions Technical College.

The canal general meeting of the Qsoociatimon was held in Belfast on

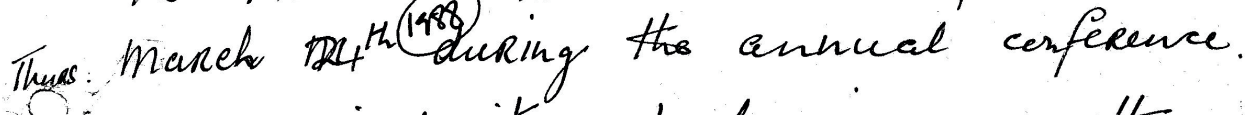
The principal item of business on the agenda was tho consideration of the draft constitution. \& the election of officers \& committer for the current year. annual sulopistion was fixed at $\frac{k}{k}$.. It was also agreed that the next

- conference would be held in bore.:

Officers elected were president T.Banat

Secretary P. billet

Treasuear T.Rigney

Those elected to council were.

y. I' Hugh, K. Warnock, Prof. E. bahill

Pro. A. Wash Prof. g. Page \& mo hern ni hongám.

Auditions of the association elided were Go ln meaghas \& I. bolter.

If was also resolved that tho possebleter of stoned be pressed. that a general.

65

IAR.indb 65

$23 / 09 / 2013 \quad 16: 58: 22$ 
Pierce, Warnock and Pierce

\section{APPENDIX 3: CONFERENCE LOCATIONS}

\begin{tabular}{|c|c|c|c|}
\hline Year & Conference & Location & Number of Papers \\
\hline 1987 & Inaugural & Trinity College Dublin & 6 \\
\hline 1988 & First & Queen's University Belfast & 12 \\
\hline 1989 & Second & University College Cork/RTC Cork & 14 \\
\hline 1990 & Third & Dublin City University & 22 \\
\hline 1991 & Fourth & University of Ulster at Jordanstown & 23 \\
\hline 1992 & Fifth & University College Galway & 26 \\
\hline 1993 & Sixth & University College Dublin & 24 \\
\hline 1994 & Seventh & Queen's University Belfast & 27 \\
\hline 1995 & Eighth & University of Limerick & 32 \\
\hline 1996 & Ninth & Regional Technical College, Dundalk & 36 \\
\hline 1997 & Tenth & Dublin City University & 40 \\
\hline 1998 & Eleventh & University of Ulster at Coleraine & 39 \\
\hline 1999 & Twelfth & University College Cork & 39 \\
\hline 2000 & Thirteenth & Dublin Institute of Technology & 45 \\
\hline 2001 & Fourteenth & Waterford Institute of Technology & 35 \\
\hline 2002 & Fifteenth & National University of Ireland, Galway & 37 \\
\hline 2003 & Sixteenth & Institute of Technology, Tallaght & 49 \\
\hline 2004 & Seventeenth & Queen's University Belfast & 43 \\
\hline 2005 & Eighteenth & University of Limerick & 48 \\
\hline 2006 & Nineteenth & Dublin City University & 41 \\
\hline 2007 & Twentieth & Institute of Technology, Tralee & 41 \\
\hline 2008 & Twenty-First & Institute of Technology, Athlone & 33 \\
\hline 2009 & Twenty-Second & University College Dublin & 40 \\
\hline 2010 & Twenty-Third & University of Ulster, Belfast & 44 \\
\hline 2011 & Twenty-Fourth & University College Cork & 48 \\
\hline 2012 & Twenty-Fifth & National University of Ireland, Galway & 54 \\
\hline $2013^{*}$ & Twenty-Sixth & Institute of Technology, Tallaght & \\
\hline
\end{tabular}

* Planned at the time of writing 
A History of the Irish Accounting and Finance Association 1987-2012

APPENDIX 4:ANALYSIS OF CONFERENCE PAPERS BY SUBJECT AREA

\begin{tabular}{|c|c|c|c|c|c|c|c|c|c|c|c|}
\hline \multicolumn{12}{|c|}{ Subject Area - Percentage of Papers } \\
\hline Year & AUD & EDUC & FACC & FIN & GOV & HIST & MAN & PUB & TAX & OTHER & TOTAL \\
\hline 1993 & 12.5 & 12.5 & 12.5 & 29.1 & 0 & 0 & 16.7 & 4.2 & 8.3 & 4.2 & 100 \\
\hline 1997 & 10 & 12.5 & 27.5 & 25 & 2.5 & 2.5 & 7.5 & 5 & 5 & 2.5 & 100 \\
\hline 2001 & 2.9 & 8.6 & 14.3 & 37.1 & 5.7 & 2.9 & 14.2 & 5.7 & 0 & 8.6 & 100 \\
\hline 2005 & 4.2 & 14.6 & 10.4 & 31.2 & 4.2 & 2.1 & 14.6 & 6.2 & 10.4 & 2.1 & 100 \\
\hline 2009 & 0 & 7.5 & 15 & 35 & 12.5 & 5 & 10 & 7.5 & 2.5 & 5 & 100 \\
\hline AUD & \multicolumn{11}{|c|}{ Auditing } \\
\hline EDUC & \multicolumn{11}{|c|}{ Accounting Education/Profession } \\
\hline FACC & \multicolumn{11}{|c|}{ Financial Accounting and Reporting } \\
\hline FIN & \multicolumn{11}{|c|}{ Finance } \\
\hline GOV & \multicolumn{11}{|c|}{ Corporate Governance } \\
\hline HIST & \multicolumn{11}{|c|}{ Accounting History } \\
\hline MAN & \multicolumn{11}{|c|}{ Management Accounting } \\
\hline PUB & \multicolumn{11}{|c|}{ Public Sector and NFP } \\
\hline TAX & \multicolumn{11}{|c|}{ Taxation } \\
\hline
\end{tabular}

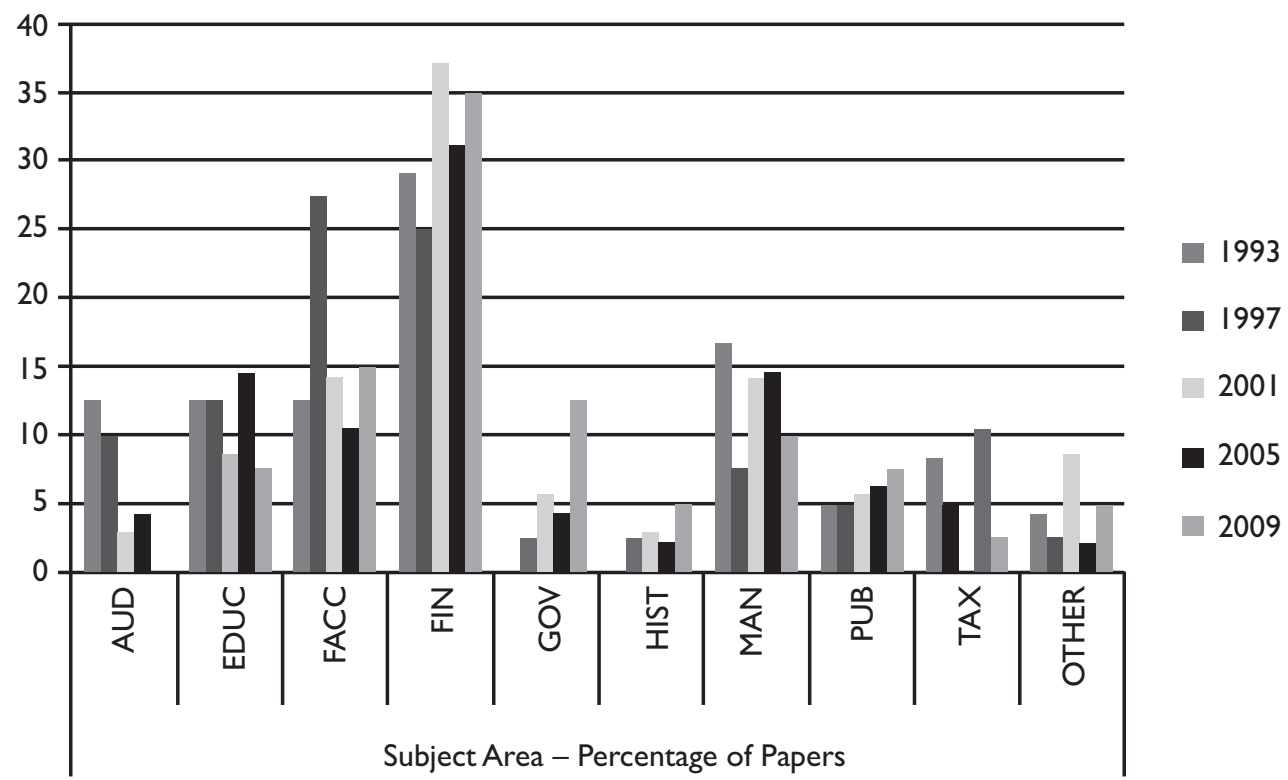


Pierce, Warnock and Pierce

APPENDIX 5:ANALYSIS OF CONFERENCE PAPERS BY AUTHORS' INSTITUTIONS

\begin{tabular}{ccccccc}
\hline \multicolumn{7}{c}{ Authors' Institutions - Percentage of Authors } \\
Year & $\begin{array}{c}\text { University } \\
\text { NI }\end{array}$ & $\begin{array}{c}\text { University } \\
\text { ROI }\end{array}$ & $\begin{array}{c}\text { University } \\
\text { Non-Irish }\end{array}$ & $\begin{array}{c}\text { Other Irish } \\
\text { Academic }\end{array}$ & $\begin{array}{c}\text { Non- } \\
\text { Academic }\end{array}$ & Total \\
\hline 1993 & 33.3 & 25.6 & 38.5 & 2.6 & 0 & 100 \\
1997 & 20 & 28.3 & 41.7 & 5 & 5 & 100 \\
2001 & 8.9 & 44.6 & 17.9 & 23.2 & 5.4 & 100 \\
2005 & 11 & 58.5 & 17.1 & 4.9 & 8.5 & 100 \\
2009 & 9.3 & 51.1 & 19.8 & 10.5 & 9.3 & 100 \\
\hline
\end{tabular}

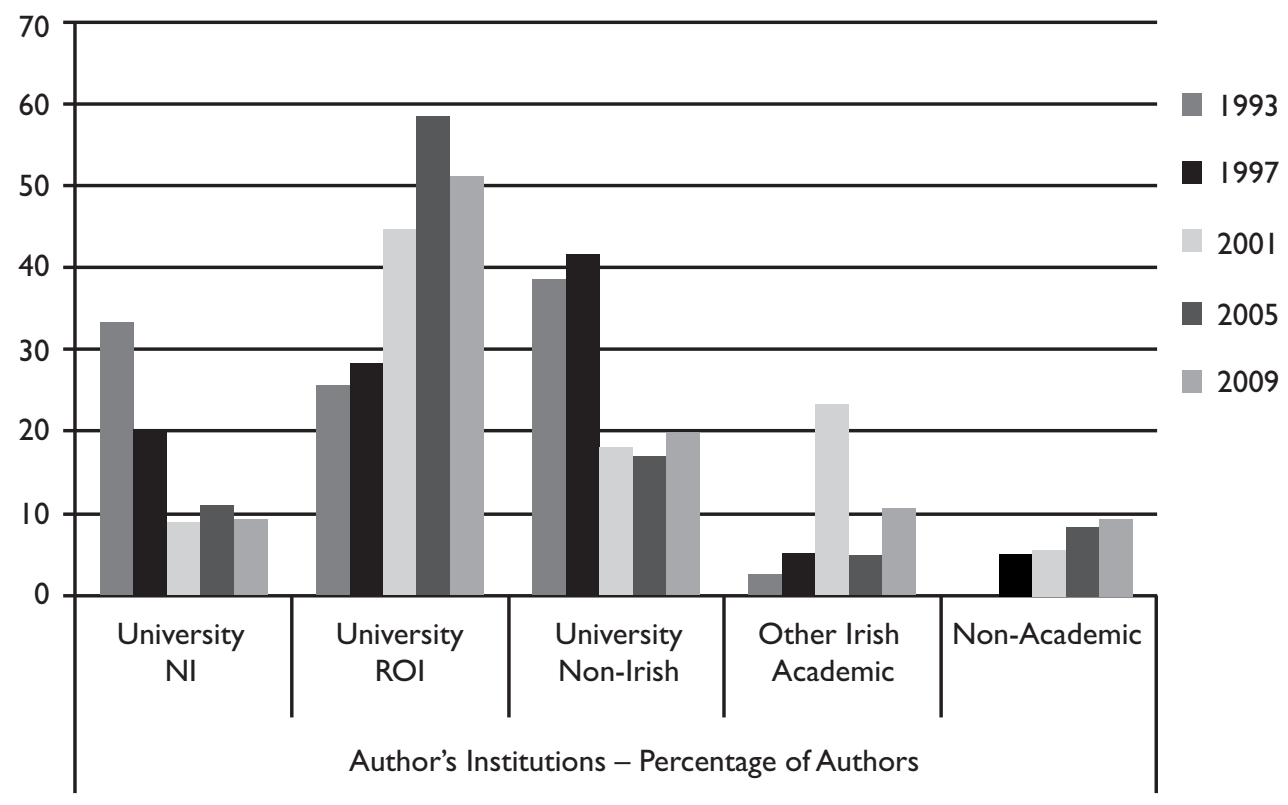


A History of the Irish Accounting and Finance Association 1987-2012

APPENDIX 6:ANALYSIS OF CONFERENCE PAPERS BY NUMBER OF AUTHORS

\begin{tabular}{lccccc}
\hline & \multicolumn{5}{c}{ Authors per Paper - Percentage } \\
Year & Single & Two & Three & Four & Total \\
\hline 1993 & 50 & 41.6 & 4.2 & 4.2 & 100 \\
1997 & 55 & 40 & 5 & 0 & 100 \\
2001 & 48.5 & 45.7 & 2.9 & 2.9 & 100 \\
2005 & 45.8 & 39.6 & 12.5 & 2.1 & 100 \\
2009 & 20 & 52.5 & 20 & 7.5 & 100 \\
\hline
\end{tabular}

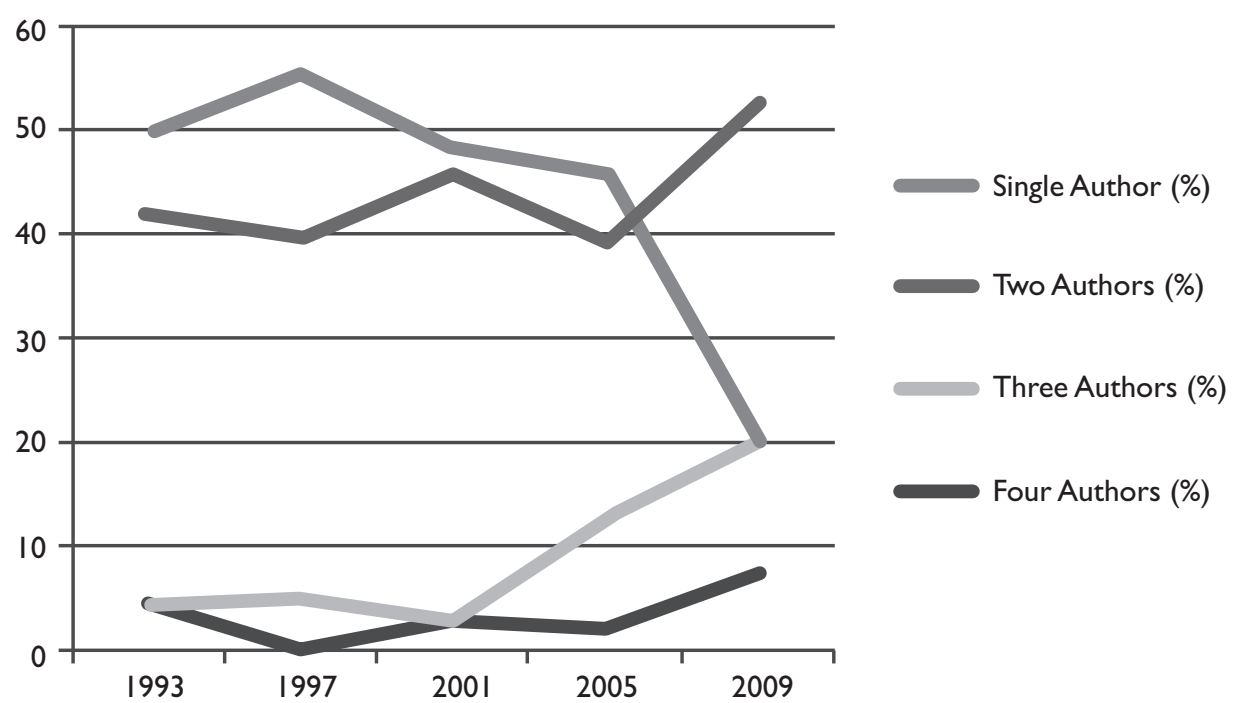


Pierce, Warnock and Pierce

APPENDIX 7: CONFERENCE PLENARY SPEAKERS AND TOPICS

\begin{tabular}{|c|c|c|c|c|}
\hline Year & Location & Speaker & Institution & Topic \\
\hline 1988 & QUB & No Plenary & $\mathrm{n} / \mathrm{a}$ & $\mathrm{n} / \mathrm{a}$ \\
\hline 1989 & $\begin{array}{l}\text { UCC/RTC } \\
\text { Cork }\end{array}$ & Joe Finnerty & $\begin{array}{l}\text { University of Illinois at } \\
\text { Urbana-Champaign }\end{array}$ & $\begin{array}{l}\text { Efficient Market Hypothesis and } \\
\text { Security Valuation }\end{array}$ \\
\hline 1990 & $\mathrm{DCU}$ & $\begin{array}{l}\text { Robert } \\
\text { Scapens }\end{array}$ & University of Manchester & $\begin{array}{l}\text { Researching Management Accounting } \\
\text { Practice - The Roles of Case Study } \\
\text { Research }\end{array}$ \\
\hline 1991 & UUJ & Pat Hewitt & CIMA & $\begin{array}{l}\text { Information Technology - The Need } \\
\text { for a Strategy and Research and } \\
\text { Development }\end{array}$ \\
\hline 1992 & UCG & $\begin{array}{l}\text { Simon } \\
\text { Keane }\end{array}$ & University of Glasgow & Stock Market Efficiency \\
\hline 1993 & UCD & $\begin{array}{l}\text { David } \\
\text { Tweedie }\end{array}$ & $\begin{array}{l}\text { Accounting Standards } \\
\text { Board }\end{array}$ & $\begin{array}{l}\text { Solid Foundations for Accounting } \\
\text { Standards }\end{array}$ \\
\hline 1994 & QUB & $\begin{array}{l}\text { Gary } \\
\text { Sundem }\end{array}$ & University of Washington & $\begin{array}{l}\text { The Accounting Education Change } \\
\text { Commission }\end{array}$ \\
\hline 1995 & UL & $\begin{array}{c}\text { Richard } \\
\text { Macve }\end{array}$ & $\begin{array}{l}\text { University of Wales, } \\
\text { Aberystwyth }\end{array}$ & $\begin{array}{l}\text { Accounting Principles and Some } \\
\text { Recent Developments in the Financial } \\
\text { Services Sector }\end{array}$ \\
\hline 1996 & $\begin{array}{l}\text { RTC } \\
\text { Dundalk }\end{array}$ & $\begin{array}{l}\text { Austin } \\
\text { Mitchell }\end{array}$ & $\begin{array}{l}\text { Member of UK } \\
\text { Parliament }\end{array}$ & Regulating the Accounting Industry \\
\hline 1997 & DCU & $\begin{array}{l}\text { Gary } \\
\text { Mueller }\end{array}$ & $\begin{array}{l}\text { Financial Accounting } \\
\text { Standards Board }\end{array}$ & $\begin{array}{l}\text { The Work of the Financial Accounting } \\
\text { Standards Board }\end{array}$ \\
\hline 1998 & $\begin{array}{l}\text { UU } \\
\text { Coleraine }\end{array}$ & $\begin{array}{l}\text { Stephen } \\
\text { Zeff }\end{array}$ & Rice University, Texas & $\begin{array}{l}\text { The Coming Confrontation on } \\
\text { International Accounting Standards }\end{array}$ \\
\hline 1999 & UCC & John Shank & $\begin{array}{l}\text { Amos Tuck School of } \\
\text { Business, Dartmouth } \\
\text { College }\end{array}$ & $\begin{array}{l}\text { The Changing World of Financial } \\
\text { Management }\end{array}$ \\
\hline 2000 & DIT & $\begin{array}{l}\text { Ron } \\
\text { Paterson }\end{array}$ & Ernst \& Young & $\begin{array}{l}\text { A Critical Appraisal of ASB's Statement } \\
\text { of Principles for Financial Reporting }\end{array}$ \\
\hline 2001 & WIT & John Purcell & $\begin{array}{l}\text { Comptroller and Auditor } \\
\text { General }\end{array}$ & $\begin{array}{l}\text { Developments in Public Accountability } \\
\text { and Audit in Ireland }\end{array}$ \\
\hline 2002 & NUI Galway & No Plenary & $\mathrm{n} / \mathrm{a}$ & $\mathrm{n} / \mathrm{a}$ \\
\hline 2003 & IT Tallaght & $\begin{array}{l}\text { Peter } \\
\text { Easton }\end{array}$ & Ohio State University & $\begin{array}{l}\text { The Practice of Valuation: Some } \\
\text { Recent Evidence }\end{array}$ \\
\hline 2004 & QUB & Mary Barth & Stanford University & $\begin{array}{l}\text { International Accounting Standards } \\
\text { and Fair Value Accounting: } \\
\text { Opportunity or Threat? }\end{array}$ \\
\hline 2005 & UL & Peter Miller & $\begin{array}{l}\text { London School of } \\
\text { Economics and Political } \\
\text { Science }\end{array}$ & $\begin{array}{l}\text { Accounting Hybrids and the } \\
\text { Management of Risk }\end{array}$ \\
\hline
\end{tabular}

(Continued) 
A History of the Irish Accounting and Finance Association 1987-2012

APPENDIX 7: (CONTINUED)

\begin{tabular}{|c|c|c|c|c|}
\hline Year & Location & Speaker & Institution & Topic \\
\hline 2006 & $\mathrm{DCU}$ & $\begin{array}{l}\text { Keith } \\
\text { Hoskin }\end{array}$ & University of Warwick & $\begin{array}{l}\text { Accounting Education:The Shaping of } \\
\text { Things to Come }\end{array}$ \\
\hline 2007 & IT Tralee & Stan Brignall & $\begin{array}{l}\text { Aston University, } \\
\text { Birmingham }\end{array}$ & $\begin{array}{l}\text { A financial perspective on financial } \\
\text { management }\end{array}$ \\
\hline 2008 & Athlone IT & $\begin{array}{l}\text { David } \\
\text { Marginson }\end{array}$ & Cardiff University & $\begin{array}{l}\text { Accounting controls cause short- } \\
\text { termism: (empirical) fact or } \\
\text { (conceptual) fiction? }\end{array}$ \\
\hline 2009 & UCD & $\begin{array}{l}\text { Stephen G. } \\
\text { Ryan }\end{array}$ & $\begin{array}{l}\text { Stern School of Business, } \\
\text { New York University }\end{array}$ & $\begin{array}{l}\text { Accounting Issues Raised by the } \\
\text { Subprime Crisis and Credit Crunch }\end{array}$ \\
\hline 2010 & UU & $\begin{array}{l}\text { Patricia } \\
\text { O’Brien }\end{array}$ & $\begin{array}{l}\text { University of Waterloo, } \\
\text { Canada }\end{array}$ & $\begin{array}{l}\text { Securitization, Transparency and } \\
\text { Failure Risk }\end{array}$ \\
\hline 2010 & UU & $\begin{array}{l}\text { Michael } \\
\text { Bromwich } \\
\text { and Al } \\
\text { Bhimani }\end{array}$ & $\begin{array}{l}\text { London School of } \\
\text { Economics and Political } \\
\text { Science }\end{array}$ & $\begin{array}{l}\text { Global Change and Management } \\
\text { Accounting: Past, Present and Future }\end{array}$ \\
\hline 2011 & UCC & Al Bhimani & $\begin{array}{l}\text { London School of } \\
\text { Economics and Political } \\
\text { Science }\end{array}$ & $\begin{array}{l}\text { Globalization and Technological } \\
\text { Disruption: Implications for the } \\
\text { Accounting Function }\end{array}$ \\
\hline 2011 & UCC & $\begin{array}{l}\text { Constantin } \\
\text { Gurdgiev }\end{array}$ & Trinity College Dublin & $\begin{array}{l}\text { Staring at the Future, but Seeing the } \\
\text { Past:The On-Going Transformation of } \\
\text { Irish Financial Services }\end{array}$ \\
\hline 2012 & NUI Galway & $\begin{array}{l}\text { Chris } \\
\text { Chapman }\end{array}$ & Imperial College London & The Research and Practice of Costing \\
\hline
\end{tabular}

APPENDIX 8: ASSOCIATION CHAIRPERSONS

\begin{tabular}{rll}
\hline Year & \multicolumn{1}{c}{ Chairperson } & \multicolumn{1}{c}{ Institution } \\
\hline $1988 / 1989$ & Tim Barrett & Queen's University Belfast \\
1989/1990 & Edward Cahill & University College Cork \\
1990/199I & Anthony Walsh & Dublin City University \\
$1991 / 1992$ & George Pogue & University of Ulster at Jordanstown \\
$1992 / 1993$ & Keith Warnock & University College Galway \\
$1993 / 1994$ & Peter Clarke & University College Dublin \\
$1994 / 1995$ & Noel Hyndman & Queen's University Belfast \\
$1995 / 1996$ & Philip O’Regan & University of Limerick \\
$1996 / 1997$ & Brian Morris & Regional Technical College, Dundalk \\
$1997 / 1998$ & Bernard Pierce & Dublin City University \\
$1998 / 1999$ & Philip Mcllkenny & University of Ulster at Jordanstown \\
$1999 / 2000$ & John Doran & University College Cork \\
\hline & &
\end{tabular}


Pierce, Warnock and Pierce

APPENDIX 8: (CONTINUED)

\begin{tabular}{rll}
\hline Year & \multicolumn{1}{c}{ Chairperson } & \multicolumn{1}{c}{ Institution } \\
\hline $2000 / 2001$ & Noel O'Brien & Dublin Institute of Technology \\
$2001 / 2002$ & John Maher & Waterford Institute of Technology \\
$2002 / 2003$ & Pauline Willis & Dublin City University \\
$2003 / 2004$ & Martin Nolan & Institute of Technology, Tallaght \\
$2004 / 2005$ & Aileen Pierce & University College Dublin \\
$2005 / 2006$ & Antoinette Flynn & University of Limerick \\
$2006 / 2007$ & Barbara Flood & Dublin City University \\
$2007 / 2008$ & Simon Quinn & Institute of Technology, Tralee \\
$2008 / 2009$ & Eoin Langan & Institute of Technology, Athlone \\
$2009 / 2010$ & Fiona Harrigan & University College Dublin \\
$2010 / 2011$ & David McAree & University of Ulster \\
$2011 / 2012$ & Steve O'Callaghan & University College Cork \\
$2012 / 2013$ & Breda Sweeney & National University of Ireland, Galway \\
\hline
\end{tabular}

APPENDIX 9: SEMINARS

\begin{tabular}{|c|c|c|c|c|}
\hline Date & Speakers & Speakers' Institutions & $\begin{array}{c}\text { Host } \\
\text { Institution }\end{array}$ & Sponsor \\
\hline |4/| |/| 992 & $\begin{array}{l}\text { John Innes } \\
\text { Falconer Mitchell }\end{array}$ & $\begin{array}{l}\text { University of Dundee } \\
\text { Edinburgh University }\end{array}$ & TCD & CIMA \\
\hline |3/| |/| 993 & $\begin{array}{l}\text { Lynne Fitzgerald } \\
\text { Irvine Lapsley }\end{array}$ & $\begin{array}{l}\text { Edinburgh University } \\
\text { Edinburgh University }\end{array}$ & TCD & CIMA \\
\hline $28 / 10 / 1994$ & George Foster & Stanford University & UCD & CIMA \\
\hline 25/II/I995 & $\begin{array}{l}\text { Robert Scapens } \\
\text { Ken Simmonds }\end{array}$ & $\begin{array}{l}\text { University of Manchester } \\
\text { London Business School }\end{array}$ & DCU & CIMA \\
\hline $\begin{array}{r}17 / 05 / 1996- \\
18 / 05 / 1996\end{array}$ & Ken Merchant & University of Southern California & DIT & CIMA \\
\hline $16 / 11 / 1996$ & Frederick Choi & New York University & UCD & $\mathrm{ACCA}$ \\
\hline |4/03/ 997 & $\begin{array}{l}\text { Andrew Likierman } \\
\text { Irvine Lapsley }\end{array}$ & $\begin{array}{l}\text { UK Government Accounting } \\
\text { Service } \\
\text { Edinburgh University }\end{array}$ & UUJ & CIMA \\
\hline $25 / 10 / 1997$ & Robert Kaplan & Harvard Business School & TCD & $\mathrm{ACCA}$ \\
\hline $26 / 02 / 1998$ & Robin Cooper & Claremont Graduate University & DIT & CIMA \\
\hline $21 / 11 / 1998$ & $\begin{array}{l}\text { Geoffrey } \\
\text { Whittington }\end{array}$ & Cambridge University & UCD & $\mathrm{ACCA}$ \\
\hline 25/02/1999 & Michael Bromwich & London School of Economics & IT Tallaght & CIMA \\
\hline 10/04/1999 & $\begin{array}{l}\text { Patricia Fraser } \\
\text { Eamonn Walsh }\end{array}$ & $\begin{array}{l}\text { University of Aberdeen } \\
\text { University College Dublin }\end{array}$ & DIT & CIMA \\
\hline
\end{tabular}

(Continued) 
APPENDIX 9: (CONTINUED)

\begin{tabular}{|c|c|c|c|c|}
\hline Date & Speakers & Speakers' Institutions & $\begin{array}{c}\text { Host } \\
\text { Institution }\end{array}$ & Sponsor \\
\hline $30 / 10 / 1999$ & Michael McDowell & $\begin{array}{l}\text { Attorney General, Republic of } \\
\text { Ireland }\end{array}$ & UCD & $\mathrm{ACCA}$ \\
\hline $25 / 11 / 1999$ & Robert Scapens & University of Manchester & UCD & \\
\hline $19 / 02 / 2000$ & Bob Berry & University of Nottingham & WIT & CIMA \\
\hline $\mathrm{I} I / \mathrm{I} / / 2000$ & Tony Tinker & City University of New York & DCU & $\mathrm{ACCA}$ \\
\hline $16 / 02 / 2001$ & $\begin{array}{l}\text { John Innes } \\
\text { Falconer Mitchell }\end{array}$ & $\begin{array}{l}\text { University of Dundee } \\
\text { Edinburgh University }\end{array}$ & IT Tallaght & CIMA \\
\hline $28 / 03 / 2002$ & $\begin{array}{l}\text { Ira Solomon } \\
\text { Timothy Bell }\end{array}$ & $\begin{array}{l}\text { University of Illinois } \\
\text { KPMG }\end{array}$ & DCU & $\mathrm{ACCA}$ \\
\hline $24 / 10 / 2002$ & Philip Brown & University of Western Australia & DIT & CIMA \\
\hline $21 / 03 / 2003$ & Robert Sack & University of Virginia & UCD & $\mathrm{ACCA}$ \\
\hline $22 / 11 / 2003$ & $\begin{array}{l}\text { Paul Appleby } \\
\text { Istemi Demirag }\end{array}$ & $\begin{array}{l}\text { Director of Corporate } \\
\text { Enforcement, Republic of Ireland } \\
\text { Queen's University Belfast }\end{array}$ & UCD & $\mathrm{ACCA}$ \\
\hline $28 / 02 / 2004$ & David Otley & Lancaster University & DIT & CIMA \\
\hline$|2 /| \mid / 2004$ & Stephen Walker & Cardiff University & DIT & $\mathrm{ACCA}$ \\
\hline $11 / 03 / 2005$ & Peter Wilson & Boston College & DCU & CIMA \\
\hline $04 / 11 / 2005$ & $\begin{array}{l}\text { Jan Bebbington } \\
\text { Roger Adams } \\
\text { lan Thompson }\end{array}$ & $\begin{array}{l}\text { University of St Andrews } \\
\text { ACCA } \\
\text { Strathclyde University }\end{array}$ & DIT & $\mathrm{ACCA}$ \\
\hline $10 / 02 / 2006$ & John Burns & University of Dundee & Athlone IT & CIMA \\
\hline $07 / 03 / 2008$ & Neil Marriott & Winchester Business School & UCC & \\
\hline $31 / 10 / 2008$ & Sven Modell & University of Manchester & QUB & CIMA \\
\hline 06/03/2009 & Paul Moxey & $\mathrm{ACCA}$ & WIT & $\mathrm{ACCA}$ \\
\hline $19 / 11 / 2009$ & Niamh Brennan & University College Dublin & $\begin{array}{l}\text { IT } \\
\text { Blanchardstown }\end{array}$ & \\
\hline $24 / 03 / 2010$ & $\begin{array}{l}\text { Christopher } \\
\text { Humphrey }\end{array}$ & University of Manchester & NUI Galway & \\
\hline
\end{tabular}


Pierce, Warnock and Pierce

APPENDIX I0: RESEARCH SEMINARS/WORKSHOPS

\begin{tabular}{|c|c|c|c|c|}
\hline Date & Speakers & Speakers' Institutions & $\begin{array}{c}\text { Host } \\
\text { Institution }\end{array}$ & Sponsor \\
\hline $08 / 12 / 1995$ & $\begin{array}{l}\text { Pauline Weetman } \\
\text { Ted O'Leary }\end{array}$ & $\begin{array}{l}\text { Heriot-Watt University } \\
\text { UCC }\end{array}$ & DCU & \\
\hline 10/05/1996 & $\begin{array}{l}\text { Andy Stark } \\
\text { Eamonn Walsh }\end{array}$ & $\begin{array}{l}\text { Manchester Business School } \\
\text { University of Limerick/New York } \\
\text { University }\end{array}$ & UCD & \\
\hline $22 / 11 / 1996$ & $\begin{array}{l}\text { Stuart Turley } \\
\text { John Forker }\end{array}$ & $\begin{array}{l}\text { University of Manchester } \\
\text { QUB }\end{array}$ & UUJ & \\
\hline 08/03/I997 & $\begin{array}{l}\text { Andrew Lymer } \\
\text { Alan Sangster }\end{array}$ & $\begin{array}{l}\text { University of Birmingham } \\
\text { QUB }\end{array}$ & QUB & Deloitte \\
\hline 09/06/1997 & $\begin{array}{l}\text { Charles Ferguson } \\
\text { John Forker }\end{array}$ & $\begin{array}{l}\text { UU Coleraine } \\
\text { QUB }\end{array}$ & DIT & ICPAI \\
\hline 26/09//997 & Stuart McLeay & University of Wales, Bangor & IT Tallaght & ICPAI \\
\hline $21 / 11 / 1997$ & Peter Moizer & University of Manchester & QUB & ICPAI \\
\hline $25 / 06 / 1998$ & $\begin{array}{l}\text { John Forker } \\
\text { Clive Emmanuel }\end{array}$ & $\begin{array}{l}\text { QUB } \\
\text { Glasgow University }\end{array}$ & Athlone IT & ICPAI \\
\hline $18 / 12 / 1998$ & David Otley & Lancaster University & DCU & ICPAI \\
\hline 20/01/1999 & $\begin{array}{l}\text { Irvine Lapsley } \\
\text { Noel Hyndman }\end{array}$ & $\begin{array}{l}\text { University of Edinburgh } \\
\text { UUJ }\end{array}$ & UUJ & ICPAI \\
\hline 26/03/1999 & Gordon Rae & UU Coleraine & DCU & ICPAI \\
\hline $\begin{array}{l}25 / 03 / 2000 \\
01 / 04 / 2000 \\
\text { and } \\
08 / 04 / 2000\end{array}$ & Philip Hamill & UUJ & DIT & ICPAI \\
\hline $30 / 1 \mathrm{I} / 2002$ & Sally Brown & $\begin{array}{l}\text { Institute for Learning and Teaching } \\
\text { in } \mathrm{HE}\end{array}$ & $\mathrm{DCU}$ & ICPAI \\
\hline $23 / 05 / 2003$ & Ted O'Leary & University of Manchester & DCU & ICPAI \\
\hline 04/02/2005 & Frank Hartmann & Nijmegen School of Management & NUI Galway & ICPAI \\
\hline $08 / 12 / 2006$ & Mike Jones & Cardiff Business School & UCD & $\mathrm{ACCA}$ \\
\hline $30 / 03 / 2007$ & Michael Humphreys & Nottingham University & $\mathrm{DCU}$ & \\
\hline 06/10/2007 & Sally Brown & Leeds Metropolitan University & UCD & ACCA \\
\hline $18 / 01 / 2008$ & $\begin{array}{l}\text { Carole Howorth } \\
\text { Christine Coupland }\end{array}$ & $\begin{array}{l}\text { Lancaster University } \\
\text { Nottingham University }\end{array}$ & DCU & IAET \\
\hline 07/05/2008 & Ruth Bender & Cranfield School of Management & Athlone IT & IAET \\
\hline $26 / 11 / 2010$ & Ted O'Leary & University of Manchester & UCD & \\
\hline $25 / 03 / 2011$ & Bill Schwarz & Stevens Institute of Technology & IT Tallaght & \\
\hline
\end{tabular}


APPENDIX II: IAFA NOMINATED CANDIDATES ON AAA DOCTORAL COLLOQUIUM

\begin{tabular}{lll}
\hline Year & \multicolumn{1}{c}{ Candidate } & \multicolumn{1}{c}{ Institution } \\
\hline 1996 & Ciarán Ó hÓgartaigh & DCU \\
1997 & Vincent O'Connell & UCC \\
1998 & Philip Hamill & QUB \\
1999 & Breda Sweeney & UCD \\
2001 & Gary Martin & UUJ \\
2002 & Mark Mulgrew & QUB \\
2003 & Anne MarieWard & QUB \\
2004 & Encarna Guillamón Saorin & UCD \\
2005 & Sean Byrne & Waterford IT \\
2009 & Collette Kirwan & Waterford IT \\
2010 & Orla Feeney & DCU \\
2011 & Sandra Brosnan & UCC \\
2012 & Graeme Banks & UU \\
\hline
\end{tabular}

\section{APPENDIX I 2: ANNUAL DOCTORAL RESEARCH FUNDING COMPETITION}

\begin{tabular}{cll}
\hline \multicolumn{1}{c}{ Year } & \multicolumn{1}{c}{ Winners } & \multicolumn{1}{c}{ Institution } \\
\hline $2008 / 2009$ & Domenico Campa & University College Cork \\
& Orla Feeney & Dublin City University \\
& Rosemarie Kelly & Waterford Institute of Technology \\
& Brid Murphy & Dublin City University \\
& & \\
$2009 / 2010$ & Graeme Banks & University of Ulster \\
& Rebecca Maughan & Dublin Institute of Technology \\
& Corina Sheerin & National College of Ireland \\
& Stewart Smyth & Dublin City University \\
& & \\
$2010 / 2011$ & Kate Cullen & University College Dublin \\
& Desmond Gibney & National College of Ireland \\
& Celine Mclnerney & University College Cork \\
& Mark Mulcahy & University College Cork \\
& & \\
& Susan Griffin & University College Dublin \\
& Fearghal Kearney & Dublin City University \\
\hline
\end{tabular}


Pierce, Warnock and Pierce

\begin{tabular}{lll} 
APPENDIX I3: IRISH ACCOUNTING REVIEW, EDITORS AND MEMBERS OF THE \\
\multicolumn{1}{c}{ Name } \\
EDITORIAL BOARD
\end{tabular}

\section{REFERENCES}

Ashton, D., Beattie, V., Broadbent, J., Brooks, C., Draper, P., Ezzamel, M., Gwilliam, D., Hodgkinson, R., Hoskin, K., Pope, P. and Stark, A. (2009). British Research in Accounting and Finance (2001-2007): The 2008 Research Assessment Exercise, British Accounting Review, Vol. 41, No. 4, pp. 199-207.

Clarke, P. (2005). The Story of Bernard F. Shields: The First Professor of Accountancy in the UK, Accounting History, Vol. 10, No. 2, pp. 103-123.

Colbert, P. (2000). IAFA News, Newsletter of the Irish Accounting and Finance Association, Vol. 5, No. 1, Summer/Autumn.

Helliar, C.V., Monk, E.A. and Hannah, G. (eds.) (2010). British Accounting Review Research Register, fourteenth edition, Amsterdam: Elsevier.

Hyndman, N., Ó hÓgartaigh, C. and Warnock, K. (2006). Patterns of Publication in Academic Accounting: Contours of a Changing Landscape in the Irish University Sector, Irish Accounting Review, Vol. 13, Special Issue, pp. 45-64.

Hyndman, N. and Warnock, K. (1997). Reviewing the Review: Looking Back and Looking Forward, Irish Accounting Review, Vol. 4, No. 2, pp. 41-54.

Irish Accounting Association (1988a). Constitution of the Irish Accounting Association, Dublin: Irish Accounting Association.

Irish Accounting Association (1988b). Minutes of the Annual General Meeting, 24 March 1988, Dublin: Irish Accounting Association.

Irish Accounting Association (1989a). Secretary's Report to the Annual General Meeting, 21 March 1989, Dublin: Irish Accounting Association.

Irish Accounting Association (1989b). Minutes of the Council Meeting, 13 September 1989, Dublin: Irish Accounting Association.

Irish Accounting Association (1989c). Minutes of the Council Meeting, 3 February 1989, Dublin: Irish Accounting Association. 
Irish Accounting Association (1990). Secretary's Report to the Annual General Meeting, 29 March, 1990, Dublin: Irish Accounting Association.

Irish Accounting and Finance Association (1992). Minutes of the Council Meeting, 26 June 1992, Dublin: Irish Accounting Association.

Irish Accounting and Finance Association (1993). Minutes of the Council Meeting, 13 November 1993, Dublin: Irish Accounting Association.

Irish Accounting and Finance Association (1994). Minutes of the Annual General Meeting, 28 March 1994, Dublin: Irish Accounting Association.

Irish Accounting and Finance Association (2000). Chairman's Report to the Annual General Meeting, 11 May 2000, Dublin: Irish Accounting Association.

Maunders, K. (1997). The AUTA/BAA 1971-1996: Living in Interesting Times, British Accounting Review, Vol. 29, Special Issue, pp. 63-79.

Parker, R.H. (1997). Flickering at the Margin of Existence: The Association of University Teachers of Accounting, 1960-1971, British Accounting Review, Vol. 29, Special Issue, pp. 41-61.

Robinson, H.W. (1964). A History of Accountants in Ireland, Dublin: Institute of Chartered Accountants in Ireland.

Sweeney, B. and Barnes, E. (eds.) (2004). Irish Accounting Directory 2004, Cork: Oak Tree Press for the Irish Accounting and Finance Association in association with the Association of Chartered Certified Accountants.

Warnock, K. and Pierce, A. (2006). Constructive Collegiality: A History of the Irish Accounting and Finance Association, Irish Accounting Review, Vol. 13, Special Issue, pp. 25-44.

Zeff, S.A. (1997). The Early Years of the Association of University Teachers of Accounting: 1947-1959, British Accounting Review, Vol. 29, Special Issue, pp. 3-39. 